\title{
ARE WE READY FOR ELECTRIC CARS?
}

\author{
Mirosław Karczewski, Leszek Szczęch, Filip Polak
}

\author{
Military University of Technology \\ Faculty of Mechanical Engineering \\ Institute of Motor Vehicles and Transportation \\ Gen. Sylwestra Kaliskiego Street 2, 00-908 Warsaw, Poland \\ e-mail:miroslaw.karczewski@wat.edu.pl \\ leszek.szczech@wat.edu.pl,filip.polak@wat.edu.pl
}

\begin{abstract}
Cars with electric drive are becoming more fashionable. More and more of them appear on the roads, especially in the centres of big cities. However, electric cars must be charged, preferably from high-power energy sources. In domestic environment, (if somebody owns a house) power available is usually of 10-16 kW. Users have to increase the level of household power or charge the car for several hours, because car charger is not the only home energy receiver. Some of the users are installing energy storage systems solution based on energy storage systems but this require additional expenses for batteries, inverter, circuit breakers and additional equipment. Other disadvantages of such solution are that they are mostly dedicated for stand-alone houses. What could be done by electric cars owners who live on the 10th floor in a block of flats? What would happen if everyone in the same time decided to buy an electric car? What will happen if everyone at the same time charges his or her cars? Do we have an adequate supply of energy potential? On the other hand, do we need to build new energy power plants? Will the electric grid cope with such a load or will have to build new transmission lines, transformer stations, and charging stations?
\end{abstract}

Keywords: electric car, car battery charger, power supply, electricity production

\section{Introduction}

The appearance of an electric car on the streets of larger cities no longer causes excessive sensation. They have an opinion of ecological vehicles that do not emit gaseous pollutants and particulates into the environment. This is only part of the truth. In fact, pollution from electric cars is not emitted in places of their exploitation but in electric power plants where electricity is produced. In Poland about $85 \%$ of electricity [1] comes from the combustion of coal (lignite and bituminous), and combustion of these fuels is accompanied by emissions of sulphur and nitrogen oxides, but also quite large amounts of particulates in various sizes (PM2.5, PM10). An additional factor is the low efficiency of energy conversion system, which results in only approximately $20 \%$ of energy coming from the fuel being delivered to the wheels of an electric vehicle. This results in increased level of electricity production as well as high emission of toxic components and greenhouse gases in comparison to cars with internal combustion engines (about $30 \%$ of energy heat is supplied to the vehicle's wheels).

\section{Electric cars potential in Poland}

The number of electric cars being driven on Polish roads is not large and at the end of 2018 was estimated to be around 2500 [10]. In 2017 about 1300 [9] new cars were registered and a constant upward trend was observed. However, electric cars require an electricity charging station to top up the "fuel". So far, there are not many of them. Innogy maintains 12 free charging stations in Warsaw [14]. Unfortunately, they are located at normal parking spaces, so access to the charging point is not always available. Tesla cars have only a few high power charging stations in Poland, although these have a power of up to $120 \mathrm{~kW}$ and allow charging the battery in 
10 minutes for another $150 \mathrm{~km}$. The Greenway network has about $15050 \mathrm{~kW}$ recharging points with plans for another 200, which will be launched by 2020. Due to limited access to professional charging stations, having an electric car in most cases means we are forced to use the household electrical network and a trip outside of the city can be a lottery, if we do not have possibility to access a network with adequate power. Available electrical power seems to be a key element during charging a car, because it determines the time spent on recharging the battery. Typically, home networks have power from $10-16 \mathrm{~kW}$ and this is the power intended to power all home electric devices. Car chargers for home use are made in several standards (City Charge Mini 2): $3.6,7.1,11$ and $22 \mathrm{~kW}$ [14]. They allow you to charge a battery with a capacity of approx. $18 \mathrm{kWh}$ in 1 to 5 hours. This is sufficient time to charge the vehicle's battery during the night, although a $22 \mathrm{~kW}$ charger will require increasing the power level for the household. With one car, this source of energy may be sufficient; it differs, though, if more than one electric car is used. For people living in a block with a dozen or so floors and no garage space inside the building, an electric car may be an inaccessible dream.

- Professional powerplant on black coal
- Professional powerplant on brown coal
- Professional powerplant on methane
- Hydropower plant
- Wind powerplants and other renewable
- Factory powerplants

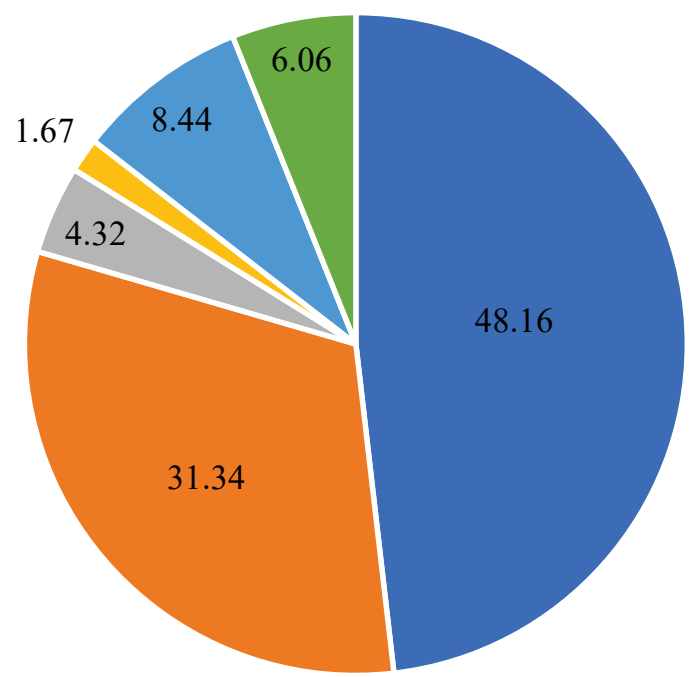

Fig. 1. Percentage share in the domestic electricity production of individual power plant groups by fuel type in 2017 [1]

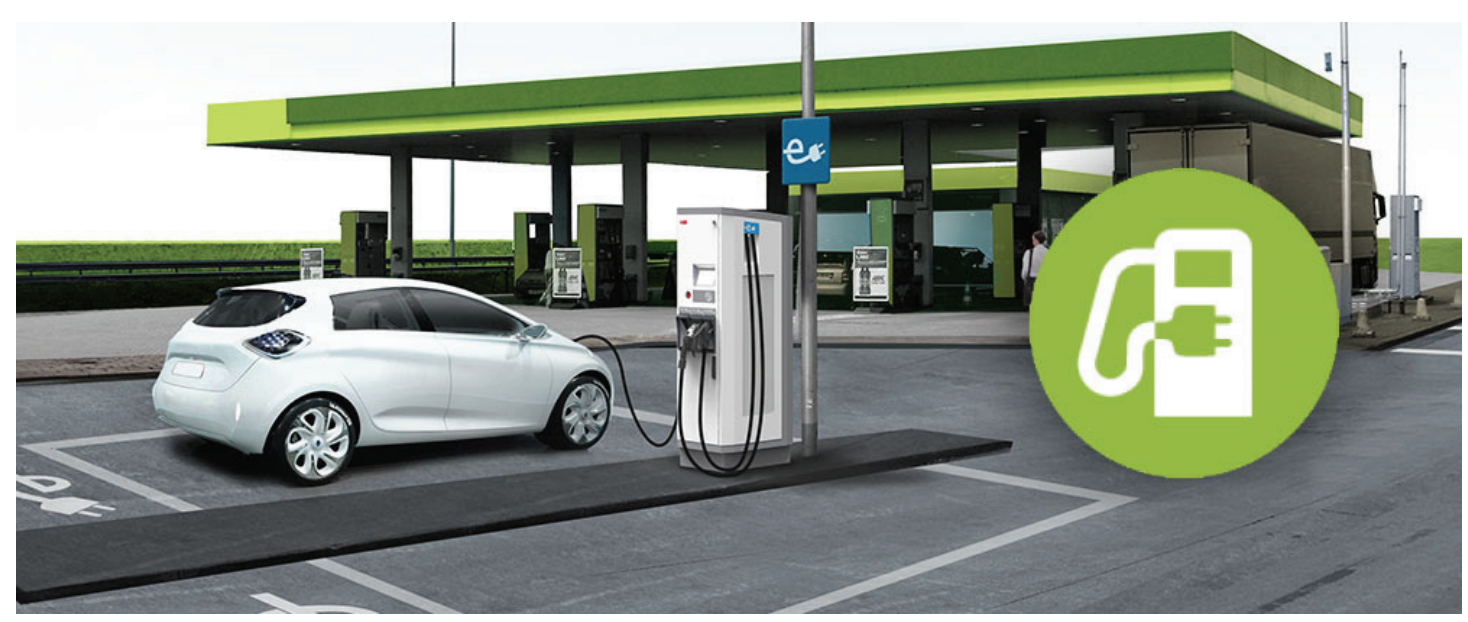

Fig. 2. Electric car charging station [3]

It is important to consider what would happen, if all owners of passenger cars decided to replace an internal combustion engine with an electric drive. The number of passenger cars registered in Poland [11] exceeds 22 million, of which approx. 14.5 million have purchased an insurance policy and about 13.5 million have passed technical inspection. The average mileage of 
passenger car in Poland is about $15000 \mathrm{~km}$ [12]. Energy consumption of an electric car is $15-20 \mathrm{kWh} / 100 \mathrm{~km}$ [5-7]. With an average energy consumption of $17.5 \mathrm{kWh} / 100 \mathrm{~km}$, electric car will use $2625 \mathrm{kWh}$ per year $(2.63 \mathrm{MWh})$. All cars that are allowed to drive, will consume about 35.5 TWh electricity per year. Because the efficiency of power grid in Poland is around $85-88 \%$ [13] and the efficiency of chargers remains at $95 \%$, power plants will have to provide additional production of approximately $42.5 \mathrm{TWh}$ of electricity.

\section{Electricity production in Poland}

Annual electricity production in Poland in 2017 reached up to $165.9 \mathrm{TWh}$. Consumption level was $168.1 \mathrm{TWh}$. The energy deficit is covered by imports, which in 2017 reached up to $2.3 \mathrm{TWh}$. The negative balance of energy exchange has persisted for the last several years [1]. Increasing energy consumption by $42.5 \mathrm{TWh}$ per year forces production growth by over $25 \%$. This means that it is necessary to build a power plant larger than the largest Bełchatów Power Plant, which covers approx. $20 \%$ of energy production with annual production at the level of 27-28 TWh. The Bełchatów Power Plant produces more than twice as much energy as the second one in turn Kozienice Power Plant [8]. Both of them should cover energy needs for all electric cars. We need new one (or more than one) power plant in Poland.

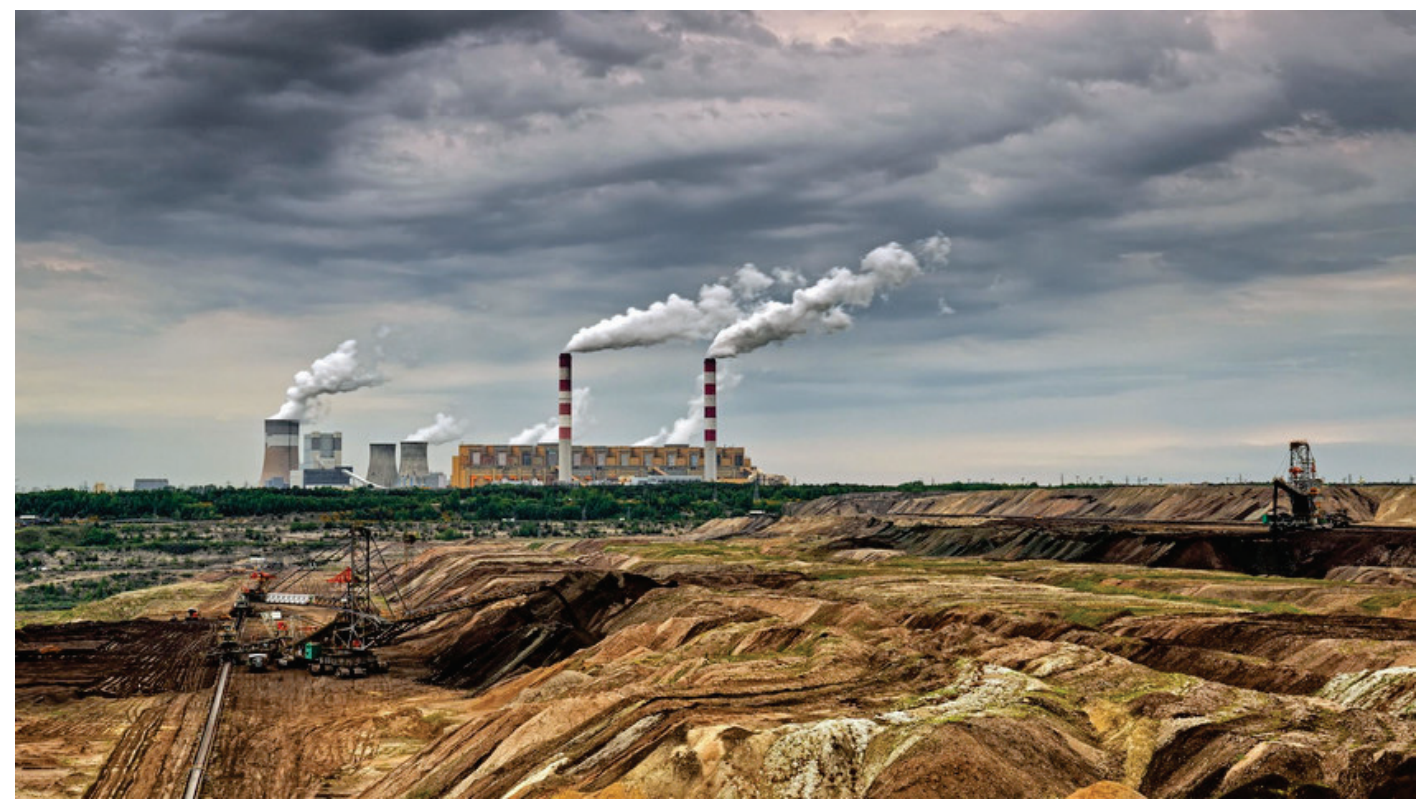

Fig. 3. Betchatów Power Station [4]

Analysing the growth rate of electricity production in Poland (in the last decade), it can be estimated that the required level will be reached around 2060 (Fig. 4).

\section{Ecological energy production for electric cars}

Electric cars in Poland would become more ecological if the energy for their power supply came from renewable sources. However, renewable energy sources have a relatively low efficiency of electricity generation. The average photovoltaic cell is able to produce approx. $140 \mathrm{~W}$ from one square meter of surface (Fig. 5). Cell energy is generated only during solar activity. In the summer months, they can produce $90 \%$ more energy than in the winter months [2]. When comparing the power of the $668 \mathrm{~W}$ photovoltaic cell to energy generated at $562 \mathrm{kWh}$, it can be estimated that this cell was operating at full power for about 850 hours a year [2]. Assuming this, the production of $42.5 \mathrm{TWh}$ of energy needed to supply electric cars will require installation 
of $50 \mathrm{GW}$ photovoltaic cells. If the cell has a power of $140 \mathrm{~W} / \mathrm{m}^{2}$, it can be estimated that cells with a total surface area of approx. $350 \mathrm{~km}^{2}$ will be needed to create the entire solar power system. This area is only slightly bigger than that of Warsaw $\left(517 \mathrm{~km}^{2}\right)$ and makes up about $0.1 \%$ of Poland's area.

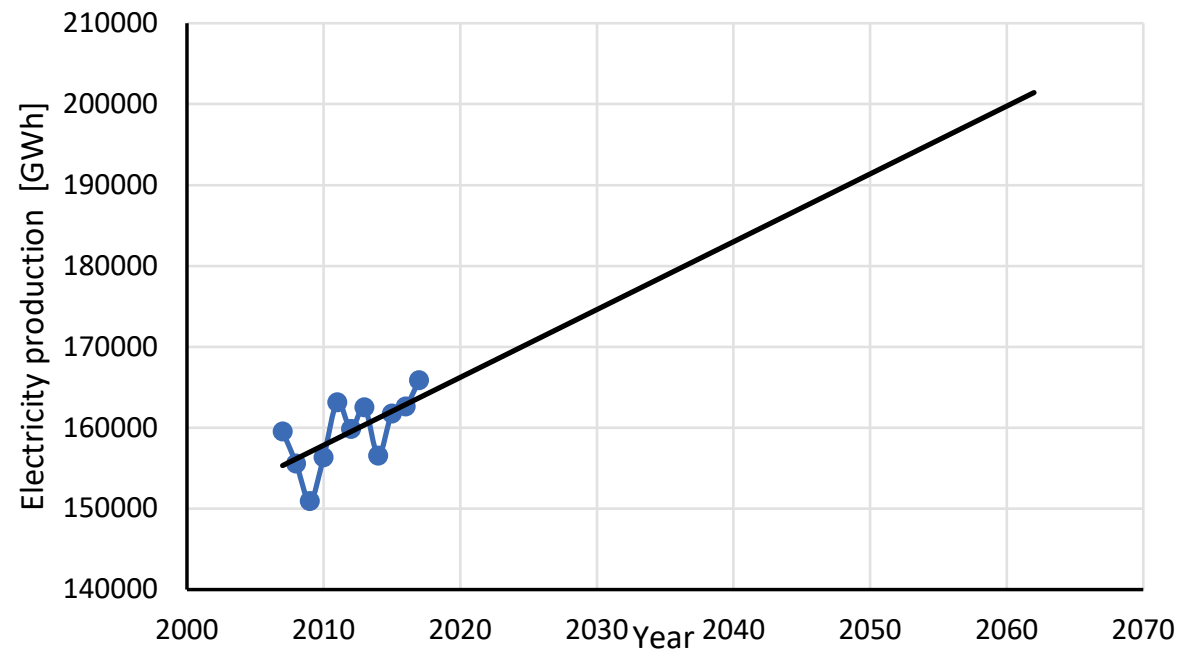

Fig. 4. Forecast of electricity production growth in Poland based on data from the last decade; own elaboration based on [1]

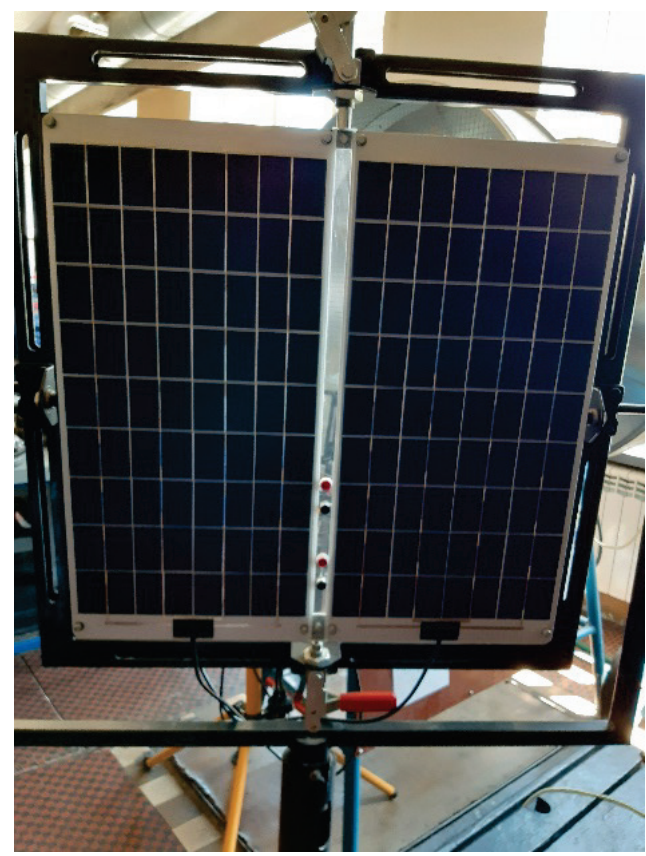

Fig. 5. Photovoltaic cell

Other sources of energy are wind and water energy. Wind energy in Poland has the biggest share in renewable energy production. Often the wind turbines are gathered in wind farms consisting of 20-30 wind turbines. "Zagórze" wind farm located near Szczecin is one of them. It consists of 15 wind turbines with power of $2 \mathrm{MW}$ each. Total power of the farm is $30 \mathrm{MW}$. It occupies an area of $225.2 \mathrm{ha}(7.5 \mathrm{ha} / \mathrm{MW})$ and produces $56-72 \mathrm{GWh}$ of energy per year [15]. To produce $42.5 \mathrm{TWh}$ per year it needs about 590-760 wind farms that occupy an area of $1330-1710 \mathrm{~km}^{2}$ ( $2 \%$ of Poland's area). This would supply clean electricity for 13.5 million of electric cars. 


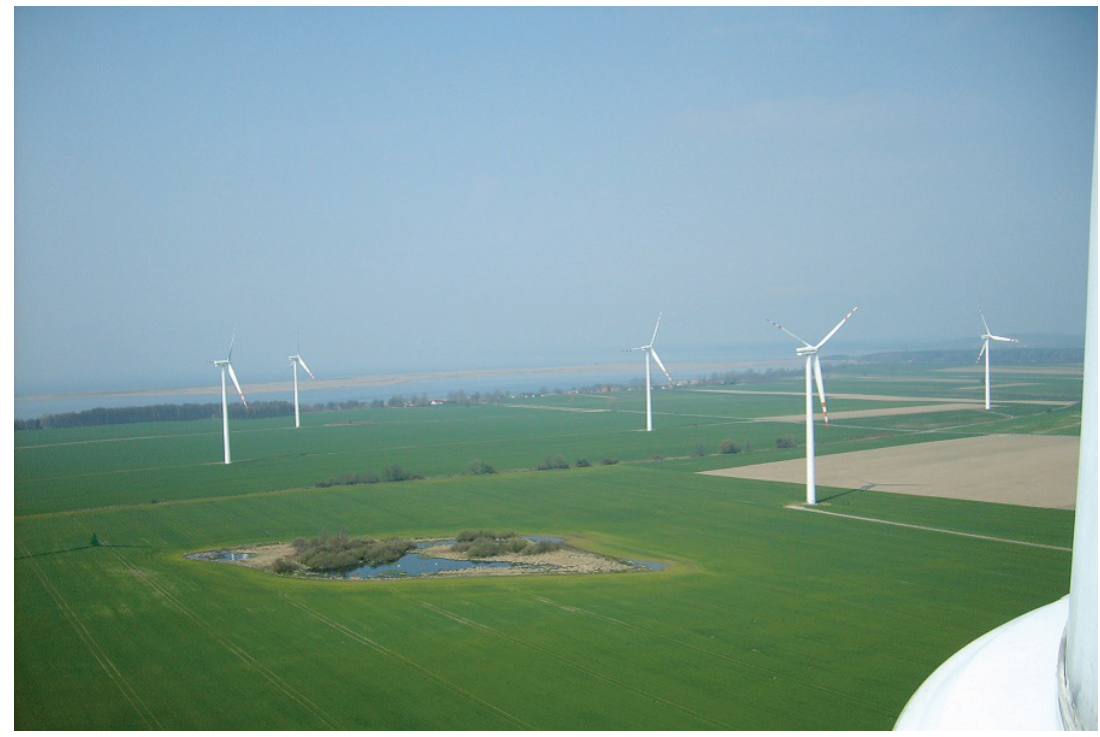

Fig. 6. The Zagórze wind farm [16]

The second most popular renewable energy source is water energy. The biggest water power plant in Poland that produces electricity is Wloclawek run-of-river hydropower plant with power capacity of 160.2 MW. In Poland, there are more hydropower plants with higher power, but they are pumped-storage hydropower plants used mainly for energy storage. Wloclawek produces $739 \mathrm{GWh}$ of energy per year. It is needed 58 new hydropower plants with similar power capacity to produce $42.5 \mathrm{TWh}$. It is important to say that in Poland we have no space for such an amount of new hydropower plants.

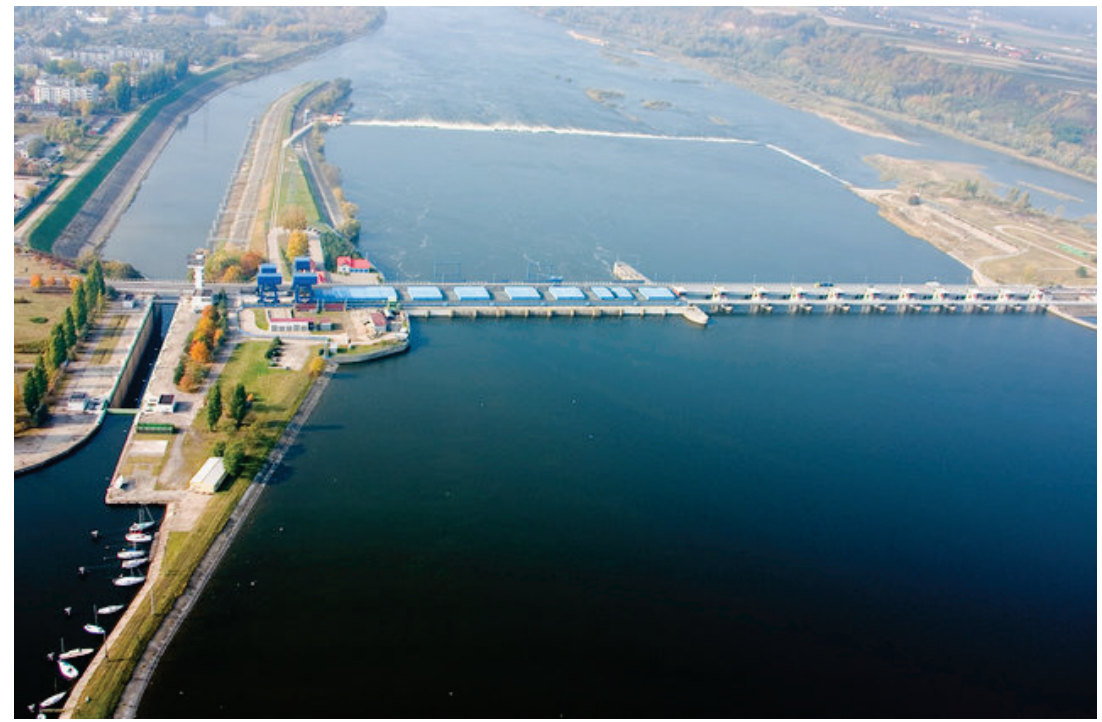

Fig. 6. The Wloclawek hydropower plant [17]

\section{Conclusions}

1) Electric cars are becoming more and more popular and we should start considering what the future energy source will be for charging their batteries.

2) The use of conventional energy sources to charge traction batteries means that over $85 \%$ of energy will be generated from non-renewable sources.

3) Replacement of IC engine of all passenger cars with electric propulsion system will result in the need to increase electricity production in Poland by over $25 \%$. 
4) Achieving the electricity production level of $200 \mathrm{TWh}$ per year, it will be possible after the year 2060.

5) In the case of a photovoltaic power plant, the supply of all electric vehicles from renewable sources will require building up a vast area of our country - around $350 \mathrm{~km}^{2}(0.1 \%$ of Poland's area).

6) In the case of wind power plant, area for electricity production may takes about $1500 \mathrm{~km}^{2}$.

7) In case of hydropower plants, we need about 60 new plants similar to Wloclawek hydropower plant.

\section{References}

[1] Zestawienie danych ilościowych dotyczacych funkcjonowania KSE w 2017 roku, Raport 2017 KSE, Polskie Sieci Energetyczne, 2017.

[2] Lenarczyk, J., Wyniki sezonowych badań wydajności energetycznej instalacji fotowoltaicznej o mocy szczytowej 668 W, Problemy Inżynierii Rolniczej PIR 2013 (I-III), Z. 1 (79) pp.151-160, 2013.

[3] http://www.inlogic.pl/blog/24/stacje-ladowania-pojazdow-elektrycznych, on the 20.06.2019.

[4] https://www.fakt.pl/pieniadze/biznes/elektrownia-belchatow-emituje-wiecej-rteci-niz-calyhisz-panski-przemys1/zwjf9n9, on the 20.06.2019.

[5] https://www.nissan.pl/pojazdy/nowe-pojazdy/leaf/zasieg-ladowania.html, on the 24.06.2019.

[6] https://elektrowoz .pl/testy/zasieg-tesla-model-3-na-autostradzie-przy-150-km-h-jest-niezleprzy-120-km-h-optymalnie-wideo/, on the 24.06.2019.

[7] http://elektrowoz.pl/porady/autostradowy-zasieg-tesla-model-s-p85d-w-zaleznosci-odszybkosci-jazdy-obliczenia/, on the 24.06.2019.

[8] https://pl.wikipedia.org/wiki/Elektrownia_Be\%C5\%82chat\%C3\%B3w Kozienicach, on the 24.06.2019.

[9] https://inzynieria.com/wpis-branzy/analizy_i_komentarze/5/54875,coraz-wiecej-autelektrycz-nych-w-polsce-raport, on the 25.06.2019.

[10] https://www.wnp.pl/motoryzacja/na-koniec-2018-roku-mielismy-w-polsce-jedynie-2-5-tysaut-elektrycznych,338344_1_0_0.html, on the 25.06.2019.

[11] Liczba pojazdów zarejestrowanych w Polsce wg. Danych CEPiK (stan na 08.08.2017), Prawo drogowe 10.07.2017.

[12] https://www.autodna.pl/blog/sredni-przebieg-auta-w-polsce-europie/, z dnia 25.06.2019.

[13] https://www.rp.pl/artykul/649811-Straty-w-przesyle-siegaja-w-kraju-12-proc-energiirocznie. html, on the 25.06.2019.

[14] https://www.innogy.pl/pl/dla-mediow/2018/innogy-polska-udostepnia-kolejne-stacjeladowania-samochodow-elektrycznych, on the 26.06.2019.

[15] https://pl.wikipedia.org/wiki/Farma_Wiatrowa_Zagórze, on the 29.07.2019.

[16] https://www.tauron-ekoenergia.pl/elektrownie/energia-wiatrowa/zagorze\#slide1, on the 29.07. 2019.

[17] https://media.energa.pl/657/pl/presskit/5746? file=668485, on the 29.07.2019.

Manuscript received 24 June 2019; approved for printing 26 September 2019 